UDC 541.73:547.458.81

\title{
SYNTHESIS AND CHARACTERIZATION OF COBALT OXIDE NANOSTRUCTURES A BRIEF REVIEW
}

\author{
S.J.Mammadyarova \\ Baku State University \\ Sevinc.memmedyarova@inbox.ru
}

Received 30.06.2020

Accepted 22.09.2020

\begin{abstract}
The newest achievement in the synthesis of cobalt oxide nanoparticles are considered. Cobalt oxide nanoparticles have attracted a great attention due to their uncommon properties and application in a supercapacitor, optoelectronic device, Li-ion battery gas sensor and electrochromic devices. Recently, nanostructured transition metal oxides with valuable properties have become a new class of materials for many technological fields. Cobalt oxide nanoparticles obtained from various precursors show different size distribution as well as different optical, electrical, magnetic, and electrochemical properties. A reduction in particle size to nanometer-scale leads to changes in properties compared to bulk ones due to quantum size effects. Depending on the application area, the choice of an appropriate synthesis method for nanoparticles with desirable properties is a crucial factor. This work aims to provide additional information on the synthesis methods and properties of cobalt oxide nanoparticles.
\end{abstract}

Keywords: cobalt oxide, crystallite size, supercapacitor.

doi

\section{Introduction}

Cobalt oxide nanoparticles $\left(\mathrm{NP}_{\mathrm{s}}\right)$ have numerous uncommon physical and chemical properties due to their quantum size effect and large surface area, in comparison with bulk counterparts. Cobalt has two stable oxides such as cobalt(II) oxide $(\mathrm{CoO})$, with a rock salt structure, and spinel cobalt (II, III) oxides $\left(\mathrm{Co}_{3} \mathrm{O}_{4}\right)$, in which $\mathrm{Co}^{2+}$ ions occupy the tetrahedral $8 a$ sites and $\mathrm{Co}^{3+}$ ions occupy the octahedral $16 d$ sites. $\mathrm{Co}_{3} \mathrm{O}_{4}$ is a $p$-type antiferromagnetic oxide semiconductor with two band gaps and it is of great importance due to its optical, catalytic, and magnetic properties. The wide application areas of cobalt oxide nanostructures are known such as anode material in Li-ion rechargeable battery, catalyst, gas sensor, supercapacitor, electrochemical sensor, solar absorbing material, $\mathrm{pH}$ sensor, electrochromic devices, smart windows, photovoltaic devices, and magnetic materials [1-11]. $\mathrm{Co}_{3} \mathrm{O}_{4}$ with a variety of morphologies such as wires, cubes, fibers, tubes, sheets, flowers, and hollow microspheres [12-18] have been reported in the literature. It is possible to change the properties of the particles by control size and morphology; therefore, minimizing the total surface energy has always been the focus of the researchers.

\section{Synthesis methods of cobalt oxide nanoparticles}

Owing to its unique physical and chemical properties and wide applications in many technological fields, cobalt oxide has attracted much attention. The most widely employed, effective synthetic techniques of cobalt oxide nanostructures are summarized, and their advantages and disadvantages are highlighted by us.

Precipitation chemical method is one of the most used methods for the synthesis of cobalt oxide nanoparticles. It consists of a twostep process: at the first stage, precipitation of different cobalt salts (sulfate, nitrate, acetate, chloride) occurs with various precipitating agents. Cobalt hydroxide $\left[\mathrm{Co}(\mathrm{OH})_{2}\right]$, cobalt oxyhydroxide $[\mathrm{CoOOH}]$, cobalt carbonate $\left(\mathrm{CoCO}_{3}\right)$ or cobalt oxalate $\left(\mathrm{CoC}_{2} \mathrm{O}_{4}\right)$ forms at this stage, cobalt oxide being obtained as a result of decomposition of these intermediate products at above $300^{\circ} \mathrm{C}$ temperature at the next stage. This method is simple, inexpensive; does not require a long reaction time and complicated equipment. Wadekar et al. [19] synthesized the amorphous structure of $\mathrm{Co}_{3} \mathrm{O}_{4}$ nanoparticles with an average crystallite size of $25.62 \mathrm{~nm}$ utilizing cobalt nitrate and sodium hydroxide $(\mathrm{NaOH})$ as precur- 
sors. Viljoen and co-workers [20] learned on the influence of anion type in cobalt salt on the size and shape of synthesized $\mathrm{Co}_{3} \mathrm{O}_{4}$ nanoparticles. They demonstrated that when cobalt nitrate was used as precursor spherical nanoparticles with a size of $6.3 \mathrm{~nm}$ were obtained while using cobalt acetate cubic nanoparticles with a size of $5.1 \mathrm{~nm}$ were obtained. $\mathrm{pH}$ is also a key factor in preparing cobalt oxide nanoparticles. Allaedini and Muhammad [21] obtained $\mathrm{Co}_{3} \mathrm{O}_{4}$ nanoparticles by this method in various $\mathrm{pH}$ conditions. Uniform and smaller nanoparticles were observed at a low $\mathrm{pH}$ value $(\mathrm{pH}=8-9)$ than higher $\mathrm{pH}$ values $(\mathrm{pH}=10-11)$. This is explained to the fact that the growth rate of particles is faster than the nucleation rate at high $\mathrm{pH}$ values. Sharifi et al. synthesized $\mathrm{Co}_{3} \mathrm{O}_{4}$ nanoparticles using $\mathrm{Co}\left(\mathrm{NO}_{3}\right)_{2} \cdot 6 \mathrm{H}_{2} \mathrm{O}$ and potassium hydroxide $(\mathrm{KOH})$ in the presence of polyvinylpyrrolidone (PVP) subsequent calcination at different high temperatures [22], wich causes the aggregation of smaller particles into bigger ones and the average diameter increased from $2 \mathrm{~nm}$ to $80 \mathrm{~nm}$. Xu et al [23] obtained porous $\mathrm{Co}_{3} \mathrm{O}_{4}$ with different morphologies using cobalt nitrate, cobalt acetate as cobalt source, and $\mathrm{NaOH}$ and ammonia as precipitating agents followed by calcination of formed $\mathrm{Co}(\mathrm{OH})_{2}$. They investigated gas-sensing action to acetone and ethanol and compared them with each other. Asa resnet of numerous research works, it has been determined that the obtained nanoparticles show mainly spherical morphology, which is difficult to control the morphology with this method.

Sol-gel method is one of the simplest and cost-effective methods for the synthesis of metal oxide nanostructures. $\mathrm{Co}_{3} \mathrm{O}_{4}$ nanoparticles with an average crystallite size of $45 \mathrm{~nm}$ by Luisetto et al. [24] using cobalt nitrate and ethyl acetate followed by thermal treatment at $450^{\circ} \mathrm{C}$ for $2 \mathrm{~h}$. Ethanol was used as a solvent. Abdelhak and colleagues [25] reported on the synthesis of $\mathrm{Co}_{3} \mathrm{O}_{4}$ thin film by the method of sol-gel dipcoating on glass substrates. Sinko et al. [26] described the synthesis of cobalt oxide nanoparticles by this method using various solvents (ethanol and 1-propanol) and surfactants [citric acid, ethyl acetate, and polydimethylsiloxane (PDMS)]. The effect of solvents and surfactants on the particle size and their size distribution were investigated. The smallest size (about 85 $\mathrm{nm})$ with narrow polydispersity $(70-100 \mathrm{~nm})$ were observed in the presence of ethyl acetate and 1-propanol. Using CTAB as surfactant $\mathrm{Co}_{3} \mathrm{O}_{4}$ nanorods with a particle size of $50 \mathrm{~nm}$ (determined by Scanning electron microscopy) were successfully synthesized by Shadrokh et al. [27]. Devi et al. [28] synthesized spinel $\mathrm{Co}_{3} \mathrm{O}_{4}$ nanoparticles by this method utilizing $\mathrm{Co}\left(\mathrm{NO}_{3}\right)_{2} \cdot 6 \mathrm{H}_{2} \mathrm{O}$, urea, $\mathrm{CTAB}$, and reported to a capacity of $620 \mathrm{~mA} \mathrm{~h} \mathrm{~g}^{-1}$. Cobalt nitrate was used in most experiments related to the synthesis of $\mathrm{Co}_{3} \mathrm{O}_{4}$ nanoparticles by the sol-gel route; the use of cobalt acetate is metrarely because due to low the solubility of cobalt chloride and cobalt sulfate in alcohol solvents.

Hydrothermal/solvothermal method is widely used for the synthesis of cobalt oxide nanomaterials of specific sizes and shapes. Wang et al. employed a this method to synthesize nanoporous $\mathrm{Co}_{3} \mathrm{O}_{4}$ nanorods, which demonstrated a high capacitance of $280 \mathrm{~F} / \mathrm{g}$ [29]. Hashemi Amiri et al. [30] described the synthesis of $\beta-\mathrm{Co}(\mathrm{OH})_{2}$ particles by this method with subsequent calcination at three different temperatures such as $300^{\circ} \mathrm{C}, 600^{\circ} \mathrm{C}$, and $900^{\circ} \mathrm{C}$ to obtain $\mathrm{Co}_{3} \mathrm{O}_{4}$. The specific surface area of nanoparticles decreased from $134 \mathrm{~m}^{2} / \mathrm{g}$ to 13 $\mathrm{m}^{2} / \mathrm{g}$ and particle size increased with rising calcination temperature. For comparison, they obtained $\mathrm{Co}_{3} \mathrm{O}_{4}$ nanoparticles in the presence of $\mathrm{H}_{2} \mathrm{O}_{2}$ as an oxidizing agent with different amounts without the need for further heating. Nassar reported the synthesis of cubic $\mathrm{Co}_{3} \mathrm{O}_{4}$ nanoparticles with an average crystallite size of $25 \mathrm{~nm}$ by thermal decomposition of cobalt carbonate at $300^{\circ} \mathrm{C}$ for $2 \mathrm{~h}$ with high yield and high purity [31]. Nugroho et al. [32] proposed supercritical hydrothermal synthesis and investigated the effect of the concentration of $\mathrm{KOH}$ acting as a reducing agent on the structure and morphology. Significant changes in morphology and particle size were observed, so that morphology of cobalt oxide changed from well faceted to irregularly shaped particles and specific surface area increases from $6.7 \mathrm{~m}^{2} / \mathrm{g}$ to $26.5 \mathrm{~m}^{2} / \mathrm{g}$ upon the addition of $\mathrm{KOH}$. Elhag et al. [33] reported 
the synthesis of cotton-like $\mathrm{Co}_{3} \mathrm{O}_{4}$ nanostructures for sensing cholesterol using sodium dodecyl sulfate (SDS) as a template. The use of template had a significant impact on morphology, when not using SDS wire-like structure and the larger size was observed, but using SDS synthesized nanostructures possess enhanced properties. Finger-like $\mathrm{Co}_{3} \mathrm{O}_{4}$ nanorods were prepared by this eco-friendly method in the presence of cobalt acetate tetrahydrate $\left(\mathrm{C}_{4} \mathrm{H}_{6} \mathrm{CoO}_{4} \cdot 4 \mathrm{H}_{2} \mathrm{O}\right)$, urea, and $\mathrm{CTAB}$ at $100^{\circ} \mathrm{C}$ for $24 \mathrm{~h}$ followed by calcination of the final product at $400^{\circ} \mathrm{C}$ for $2 \mathrm{~h} \mathrm{[34].} \mathrm{This} \mathrm{nanostructure}$ was considered a potential electrode for a supercapacitor application and exhibits a specific capacitance of $265 \mathrm{~F} / \mathrm{g}$ at $2 \mathrm{mV} / \mathrm{s}$. Another astonishing case is the successful synthesis of $\mathrm{Co}_{3} \mathrm{O}_{4}$ nanocrystals by a solvothermal reaction in an alcohol-water solvent at $160^{\circ} \mathrm{C}$ from common $\mathrm{Co}_{2} \mathrm{O}_{3}$ powder as a precursor for the first time [35]. It was concluded that reaction time, type, and concentration of solvent affect the structure and nanoparticle size. When the reaction time extended from 6 to $24 \mathrm{~h}$ nanoparticle size increased from $30 \mathrm{~nm}$ to $38 \mathrm{~nm}$, crystallinity also increases. When using pure ethanol, the nanoparticles composed of $\mathrm{Co}_{3} \mathrm{O}_{4}$ and $\mathrm{CoO}$ with a smaller size (about $25 \mathrm{~nm}$ ) were observed due to the reducing ability of alcohol. Nassar et al. [36] used Co(II)-1,3-bis(Salicylaldimine)urea complexes as a new precursor prepared by the solvothermal reaction of urea, salicylaldehyde, and cobalt chloride at $120^{\circ} \mathrm{C}$ for $2 \mathrm{~h}$. The porous mixed-phase $\mathrm{CoO} / \mathrm{Co}_{3} \mathrm{O}_{4}$ nanocomposites with an average diameter of $5 \pm 2 \mathrm{~nm}$ have been prepared using ethanol as solvent at $160^{\circ} \mathrm{C}$ for $8 \mathrm{~h}$ without further calcination and show a high capacitance of $451 \mathrm{~F} / \mathrm{g}$ at a current density of $1 \mathrm{Ag}^{-1}$ as an electrode for supercapacitor application [37].

Sonochemical method is a promising route for the preparation of various metal oxide nanostructures. It is based on the acoustic cavitation phenomenon such, as nucleation, growth, and collapse of a large number of microbubbles in a liquid medium, that can cause causes local hot spots with a temperature of around $5000^{\circ} \mathrm{C}$ under pressures of $500 \mathrm{~atm}$, heating and cooling rates of more than $10^{10} \mathrm{~K} / \mathrm{s}$. These extreme conditions lead to an influence on the structure, morphology, and size of synthesizing materials. The main advantage of this method is that it is possible to control size by altering the sonication time, ultrasonic power, current density, and concentration of precursors. Al-Qirby et al. [38] reported the synthesis of $\mathrm{Co}_{3} \mathrm{O}_{4}$ nanoparticles by an ultrasound-assisted method in the presence of ionic liquid 1-Ethyl-3-methylimidazolium tetrafluoroborate [EMIM] $\left[\mathrm{BF}_{4}\right]$ as a reaction medium for the first time. They also investigated sonication time and different molar ratios of the ionic liquid affect the nanoparticle size, chemical, and physical properties. The formation mechanism of oxide was proposed. Askarinejad and Morsali proposed the synthesis of $\mathrm{Co}_{3} \mathrm{O}_{4}$ nanocrystals with different sizes and morphologies by a one-step sonochemical method [39]. Cubic shape $\mathrm{Co}_{3} \mathrm{O}_{4}$ nanocrystals with an average size of $19 \mathrm{~nm}$ were observed using 0.1 $\mathrm{M} \mathrm{Co}\left(\mathrm{CH}_{3} \mathrm{COO}\right)_{2}$ and $0.2 \mathrm{M}$ tetramethylammonium hydroxide (TMAH) as precursors at $1 \mathrm{~h}$ sonication time and 15-18 W ultrasound power. Irregular shapes between spherical and facet with poor crystallinity were observed from transmission electron microscopy (TEM) measurements when lower ultrasound power (6-9 W) was applied and using cobalt salt and $\mathrm{NaOH}$ with the same concentrations $(0.1 \mathrm{M})$. Kamar et al. [40] obtained $\mathrm{Co}_{3} \mathrm{O}_{4}$ /graphene nanocomposites for application as a counter electrode in dye-sensitized solar cells.

Chemical bath deposition method (CBD) is one of the simplest and cheapest techniques to prepare transition metal oxides. Xia and co-workers deposited a highly porous cobalt oxide thin film on indium tin oxide (ITO) substrate at room temperature using cobalt sulfate, potassium persulfate, and ammonia. The porous structure and large surface area of thin films enhanced electrochromic performance since it can facilitate the contact between the electrolyte and the oxide surface [41]. Using the same synthesis method $\mathrm{Li}$ and colleagues employed $\mathrm{Co}_{3} \mathrm{O}_{4}$ thin film for an electrochemical capacitor which shows a maximum specific capacitance of $227 \mathrm{~F} / \mathrm{g}$ at the specific current of 
$0.2 \mathrm{Ag}^{-1}$ [42]. Lokhande et al [43] reported on the synthesis of cobalt oxide on glass and copper substrates using cobalt chloride and ammonia, in which transformation of oxyhydroxide to oxide occurs at $350^{\circ} \mathrm{C}$. It has been concluded that the nature of the substrate has significantly affected the structural properties, crystallinity and morphology of films. Interconnected flack morphology was observed on the glass substrate, while nanoworm morphology was observed on the copper substrate. In another work, they used cobalt oxide thin film prepared on copper substrate by this method for supercapacitor application, which exhibited the highest specific capacitance of $118 \mathrm{~F} / \mathrm{g}$ [44]. In another work, they also employed these thin films for the detection of acetaminophen [45]. The electrode modified with $\mathrm{Co}_{3} \mathrm{O}_{4}$ obtained using cobalt chloride demonstrated the high electrocatalytic properties. Ezema et al. deposited $\mathrm{Co}_{3} \mathrm{O}_{4}$ thin films on glass and FTO substrates at $70^{\circ} \mathrm{C}$ bath temperature changing the $\mathrm{pH}$ between 10 and 12 [46]. It was observed that a sample of pH 12 showed a maximum specific capacitance of $1576 \mathrm{~F} / \mathrm{g}$, an energy density of 245.98 $(\mathrm{Wkh} / \mathrm{kg})$, and a power density of $2.08(\mathrm{~W} / \mathrm{kg})$.

Properties of cobalt oxide nanoparticles. Cobalt oxide nanoparticles have tunable physical and chemical properties with enhanced performance over their bulk counterparts.We will selectively summarize the main and general properties of cobalt oxide nanostructures.

Optical and electrical properties. Martínez-Gil et al. [47] studied the influence of annealing temperature on the $\mathrm{Co}_{3} \mathrm{O}_{4}$ thin films synthesized using cobalt sulfate and triethanolamine. The amorphous phase was observed in all the samples and annealing temperature did not affect the morphology. Optical and electrical properties vary with increasing annealing temperature. The resistivity of the films changed between $4.29 \cdot 10^{3}$ and $1.32 \cdot 10^{7} \Omega \cdot \mathrm{om}$. These results and band diagram behavior of thin films suggest potential application in supercapacitors as electrode and optoelectronic devices. Valanarasu et al. [48] deposited $\mathrm{Co}_{3} \mathrm{O}_{4}$ thin films on a glass substrate at various $\mathrm{pH}$ values. $\mathrm{pH}$ influences the thickness, optical and electri- cal properties of thin films. The film growth rate and thickness increase, the optical band gap decreases from 2.31 to $2.16 \mathrm{eV}$ with increasing $\mathrm{pH}$ value. To improve optical and electrical properties thin films were doped with different transition metals $(\mathrm{Ni}, \mathrm{Mn}, \mathrm{Cu})$ and significant changes were observed [49]. The band gap values decreased compared to undoped $\mathrm{Co}_{3} \mathrm{O}_{4}$. Patil et al. [50] investigated the influence of temperature on the physical properties of $\mathrm{Co}_{3} \mathrm{O}_{4}$ thin film deposited on a glass substrate using a sol-gel spin technique. The crystallinity and mean crystallite size increases from 53 to $69 \mathrm{~nm}$; the optical band gap and film thickness decrease with increasing annealing temperature from 400 to $700^{\circ} \mathrm{C}$. Khansari et al. [51] descrybed the synthesis of $\mathrm{Co}_{3} \mathrm{O}_{4}$ nanohexagonales $(30 \mathrm{~nm})$ thermal treatment of $\mathrm{Co}$ (salen) precursor at $500^{\circ} \mathrm{C}$ for 5h. Khalaji prepared $\mathrm{Co}_{3} \mathrm{O}_{4}$ nanoparticles with one direct band gap of $2.3 \mathrm{eV}$ thermal decomposition of mononuclear acyclic cobalt(II) complex $[\mathrm{CoL}]\left(\mathrm{NO}_{3}\right)_{2}$ ( $\mathrm{L}=3,3^{\prime}$-dimethoxy-2,2'-(propane1,3-diyldioxy)dibenzaldehyde) at $450^{\circ} \mathrm{C}$ for $3 \mathrm{~h}$ in air [52]. $\mathrm{Co}_{3} \mathrm{O}_{4}$ nanoparticles with two band gaps (2.20 and $3.55 \mathrm{eV}$ ) were obtained from carbonatotetra(ammine)cobalt(III) nitrate complex, $\left[\mathrm{Co}\left(\mathrm{NH}_{3}\right)_{4} \mathrm{CO}_{3}\right] \mathrm{NO}_{3} \cdot \mathrm{H}_{2} \mathrm{O}$ at low-temperature decomposition $\left(175^{\circ} \mathrm{C}\right)$ [53]. Nanoporous $\mathrm{Co}_{3} \mathrm{O}_{4}$ hierarchical nanoflowers with band gaps of 1.49 $\mathrm{eV}$ and $1.98 \mathrm{eV}$ have been prepared by the hydrothermal method using $\mathrm{Co}\left(\mathrm{NO}_{3}\right)_{2}$ and urea [CO $\left(\mathrm{NH}_{2}\right)_{2}$ ] [54]. $\mathrm{Co}_{3} \mathrm{O}_{4}$ nanocubes with band gaps of $1.58 \mathrm{eV}$ and $3.40 \mathrm{eV}$ were prepared by a one-step hydrothermal process in the presence of sodium dodecylbenzene sulfonate (SDBS) at $160^{\circ} \mathrm{C}$ reaction temperature for $36 \mathrm{~h}$ [55]. Recently, Turan et al. investigated the change in $\mathrm{Co}_{3} \mathrm{O}_{4}$ optical and electrical properties by varying the bath temperature and deposition time [56]. They prepared films on microscope glass substrate using cobalt(II)chloride as a source of $\mathrm{Co}^{2+}$ and aqueous ammonia solution (25 mass.\%) followed by annealing of $\mathrm{CoO}(\mathrm{OH})$ at $300^{\circ} \mathrm{C}$ for $1 \mathrm{~h}$. When the bath temperature was increased from 65 to $95^{\circ} \mathrm{C}$, the electrical conductivity increased from about $1.37 \cdot 10^{-6}$ to $2.40 \cdot 10^{-2}(\Omega \cdot \mathrm{Om})^{-1}$. This fact was explained by enhancement in crystallinity of films. The carri- 
er concentration increased with increasing bath temperature from $8.57 \cdot 10^{21}$ to $1.50 \cdot 10^{26}(\mathrm{~m})^{-3}$ and film thickness decreased with increasing deposition time at both temperatures. Two absorption bands (around at 400 and at $700 \mathrm{~nm}$ ) were observed for cobalt oxide thin films deposited on glass and silicon substrates using the reactive radio-frequency sputtering method (Figure 1). The optical band gap and electrical resistivity of films increased with increasing oxygen pressure in the sputtering atmosphere [57]. The measured band gap is $1.46 \mathrm{eV}$ and $1.87 \mathrm{eV}$ for thin films synthesized at $10 \%$ oxygen pressure whereas it is $1.50 \mathrm{eV}$ and $2.17 \mathrm{eV}$ for films synthesized at $50 \%$ oxygen pressure. The optical band gap is $4.10 \mathrm{eV}$ for the $\mathrm{Co}_{3} \mathrm{O}_{4}$ nanoparticles produced by the hydrothermal method using thioglycolic acid as a fuel. The synthesized nanoparticles were applied for dyesensitized solar cells application. The shifting of absorption edge to lower wavelength and increasing of the band gap is due to the quantum size confinement [58]. Alla et al. [59] studied the improvement in electric properties of zirconium substituted $\mathrm{Co}_{3} \mathrm{O}_{4}$ nanoparticles produced by the single-step microwave refluxing method. Composition and frequency-dependent electric properties have been measured in the frequency range of $10 \mathrm{kHz}$ to $20 \mathrm{MHz}$. It was noticed that $\mathrm{Co}_{3} \mathrm{O}_{4}$ nanoparticles with higher zirconium concentration $(x \geq 0.1)$ showed better conductivities compared to lower ones $(x \leq 0.05)$. At higher frequencies $\mathrm{Co}^{2+}$ ion converts into $\mathrm{Co}^{3+}$ ion
$\left(\mathrm{Co}^{2+}-1 \mathrm{e}^{-} \rightarrow \mathrm{Co}^{3+}\right)$ by losing an electron. It made possible that the net charge on both sites is positive rather than neutral and causes high conductivity values of high concentration zirconium substituted samples. It was concluded that surface morphology, size, and shape of nanoparticles influences the electric properties. In their other research work, they produced cobalt oxide nanoparticles doping with zinc using the same method. An increase in conductivity at high frequencies was also observed for these samples. The low conducting behavior and the lowest dielectric constant for samples with $\mathrm{Zn}$ concentration $x=0.05$ and 0.5 are attributed to their narrow grain size distribution (Figure 2)[60]. The relative permittivity of $\mathrm{Co}_{3} \mathrm{O}_{4}$ nanolaminates grown by atomic layer deposition was found to be 30 at the applied electric field frequency of $1000 \mathrm{~Hz}$ [61]. Sayed and Gamal investigated the electrical and dielectric properties of sodium carboxymethyl cellulose (NaCMC)/polyvinyl alcohol (PVA) composite films doped with $\mathrm{Co}_{3} \mathrm{O}_{4}$ at different concentrations. It has been determined that dielectric permittivity and dielectric loss increased with increasing $\mathrm{Co}_{3} \mathrm{O}_{4}$ content. This fact was explained with increasing in charge carrier density and micro-Brownian motion of long-chain segments in the amorphous regions of CMC/PVA, respectively. The enhancement in electrical and dielectric properties with $\mathrm{Co}_{3} \mathrm{O}_{4}$ doping makes possible the application of this nanocomposite film in several industrial and electronic devices [62].

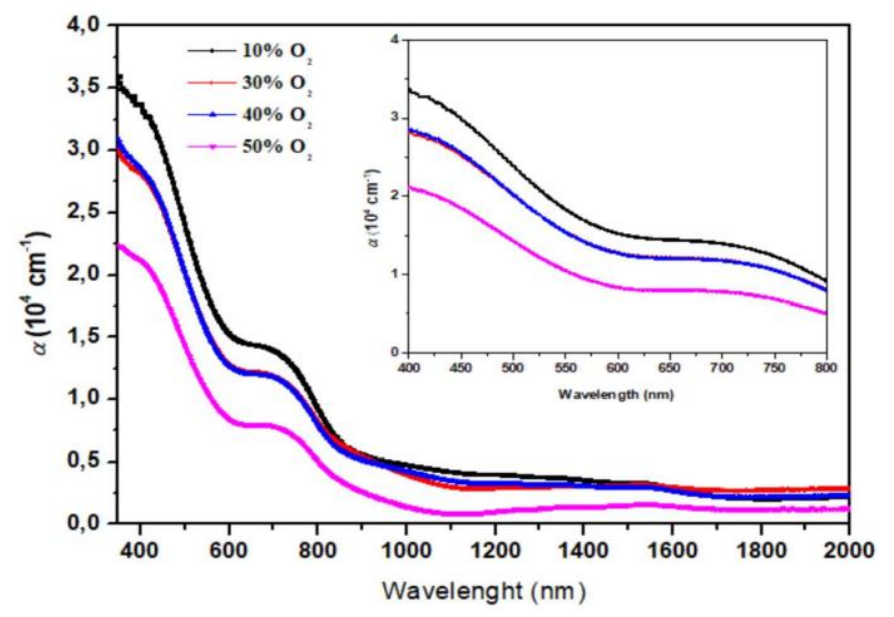

Fig. 1. Absorption spectra of $\mathrm{Co}_{3} \mathrm{O}_{4}$ thin films at different oxygen pressure [57]. 

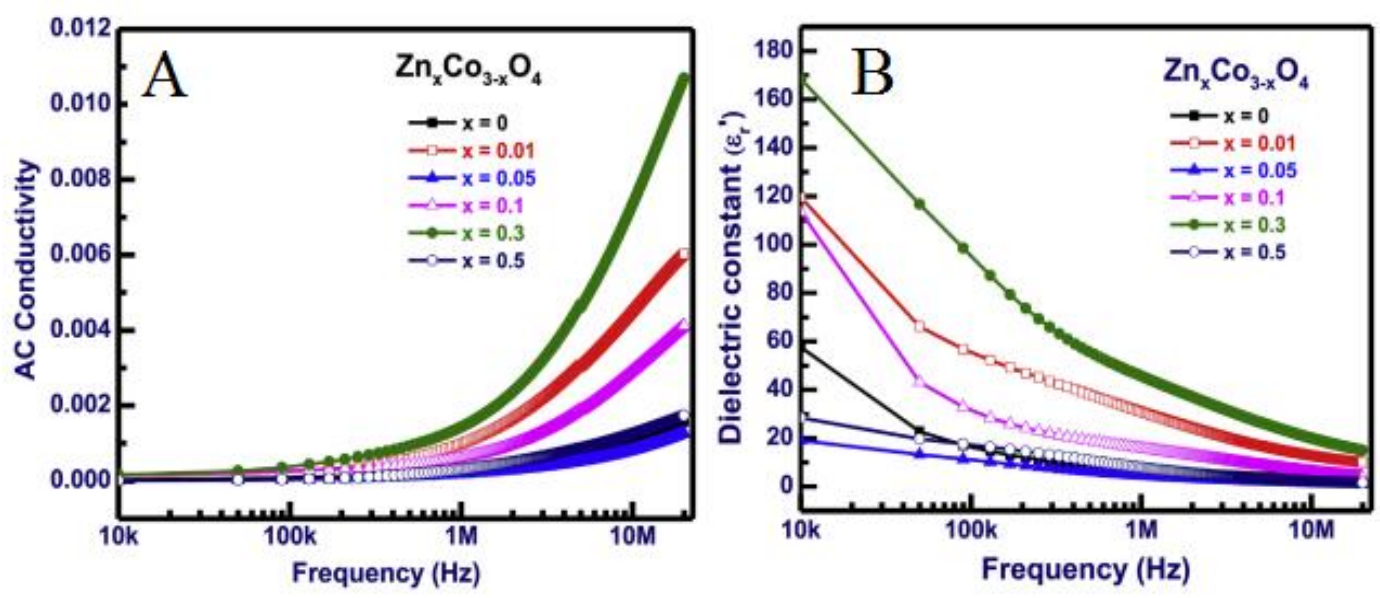

Fig. 2. a) Change in the AC conductivity as a function of the frequency of the electric ficed with electric field frequency for $\mathrm{Zn}_{x} \mathrm{Co}_{3-x} \mathrm{O}_{4}(x=0,0.01,0.05,0.1,0.3$ and 0.5$)$ samples; $b$ ) Change in the permituity with the frecnency of the electrik field for $\mathrm{Zn}_{x} \mathrm{Co}_{3-x} \mathrm{O}_{4}(x=0,0.01,0.05,0.1,0.3$ and 0.5$)$ samples [60].

\section{Catalytic, Photocatalytic, Electro- catalytic properties}

$\mathrm{Co}_{3} \mathrm{O}_{4}$ nanorods were prepared in the presence of cobalt chloride and urea and applied as a catalyst for the hydrolysis of sodium borohydride by Durano et al. [63]. $\mathrm{Co}_{3} \mathrm{O}_{4}$ nanoaggregates were synthesized using $\mathrm{CoCl}_{2} \cdot 6 \mathrm{H}_{2} \mathrm{O}$ and sodium carbonate as precursors, under decomposition of $\mathrm{CoCO}_{3}$ at $500^{\circ} \mathrm{C}$ for $3 \mathrm{~h}$ and proved to be an efficient catalyst for thermal decomposition of ammonium perchlorate [64]. Pudukudy et al. [65] described the synthesis of mesoporous spinel $\mathrm{Co}_{3} \mathrm{O}_{4}$ nanosheets with the mean crystallite size using Pluronic P123 triblock copolymer as a stabilizing agent and it has been applied as photocatalyst for the degradation of methylene blue under UV light irradiation. Farhadi et al. [66] reported the synthesis of spherelike $\mathrm{Co}_{3} \mathrm{O}_{4}$ nanoparticles with an average size of $17.5 \mathrm{~nm}$ using pentamminecobalt(III) complex $\left[\mathrm{Co}\left(\mathrm{NH}_{3}\right)_{5}\left(\mathrm{H}_{2} \mathrm{O}\right)\right]\left(\mathrm{NO}_{3}\right)_{3}$ at relatively low temperature $\left(175^{\circ} \mathrm{C}\right)$. The synthesized nanoparticles have been proved an efficient photocatalyst for the degradation of methylene blue. Kang and Zhou obtained $\mathrm{Co}_{3} \mathrm{O}_{4}$ nanocubes as a catalyst for the thermal decomposition of ammonium perchlorate (AP) [67]. They investigated the effect of a mole ratio of surfactant to $\mathrm{Co}^{2+}$, reaction temperature, and time on the growth mechanism of nanoparticles in detail. The molar ratio of polyvinylpyrrolidone (PVP) to $\mathrm{Co}^{2+}$ equal to 0.002 and $120^{\circ} \mathrm{C}$ reaction temperature for $27 \mathrm{~h}$ was chosen as optimal reaction parameters. Ren et al. [68] described the synthesis of $\mathrm{Co}_{3} \mathrm{O}_{4}$ nanoflowers, nanoplates, nanoneedles utilizing various cobalt salts, precipitating agents, and investigated catalytic activity toward toluene oxidation. It has been determined that 3D$\mathrm{Co}_{3} \mathrm{O}_{4}$ nanoflower exhibited better stability as catalyst compared to the other two nanostructures, achieving $\mathrm{T}_{90}$ at $238^{\circ} \mathrm{C}$ at a space velocity $(\mathrm{WHSV}=48.000 \mathrm{~mL} / \mathrm{g} \cdot \mathrm{h})$. Kung et al. presented a chemical bath deposition method in which $\mathrm{Co}_{3} \mathrm{O}_{4}$ thin films were deposited onto conducting fluorine-doped tin oxide (FTO) substrate in the presence of different anions for hydrogen peroxide $\left(\mathrm{H}_{2} \mathrm{O}_{2}\right)$ in sensor application [69]. Thin films with various morphology such as straight acicular nanorods, bending acicular nanorods, nanosheets, and net-shaped nanosheets were obtained using different cobalt sources. They found that the best electrocatalytic activity toward $\mathrm{H}_{2} \mathrm{O}_{2}$ was observed from electrode synthesized in the presence of cobalt chloride. Behling and co-workers used $\mathrm{Co}_{3} \mathrm{O}_{4}$ nanoparticles synthesized by the co-precipitation route as a catalyst for sonochemical oxidation of vanillyl alcohol to vanillin. They also discussed the influence of reaction parameters, catalyst loading, and hydrogen peroxide concentration on the yield and selectivity of vanillin product. It has been determined that vanillin was not formed in the absence of $\mathrm{Co}_{3} \mathrm{O}_{4}$ catalyst and vanillin yields decreased with an increasing amount of 
catalyst due to the overoxidation. When used 2 mass. $\% \mathrm{Co}_{3} \mathrm{O}_{4}$, maximum yields of vanillin were observed [70]. Dong et al. explained that the catalytic property of the as-prepared $\mathrm{Co}_{3} \mathrm{O}_{4}$ nanofibers towards glucose oxidation in alkaline solution is related to $\mathrm{CoOOH}$ and $\mathrm{CoO}_{2}$, which reversible

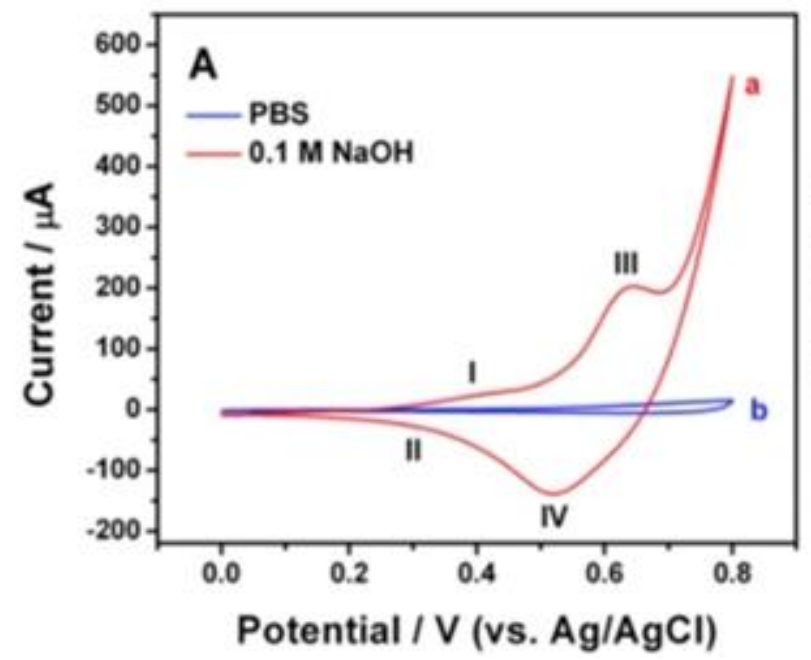

reactions are described in research work [71].

Liu et al. [72] employed a one-pot hydrothermal method for the synthesis of flower-like $\mathrm{Co}_{3} \mathrm{O}_{4} /$ graphitic carbon nitride $\left(\mathrm{Co}_{3} \mathrm{O}_{4} / g-\mathrm{C}_{3} \mathrm{~N}_{4}\right)$ nanocomposite and its electrochemical behavior was investigated using cyclic voltammetry.

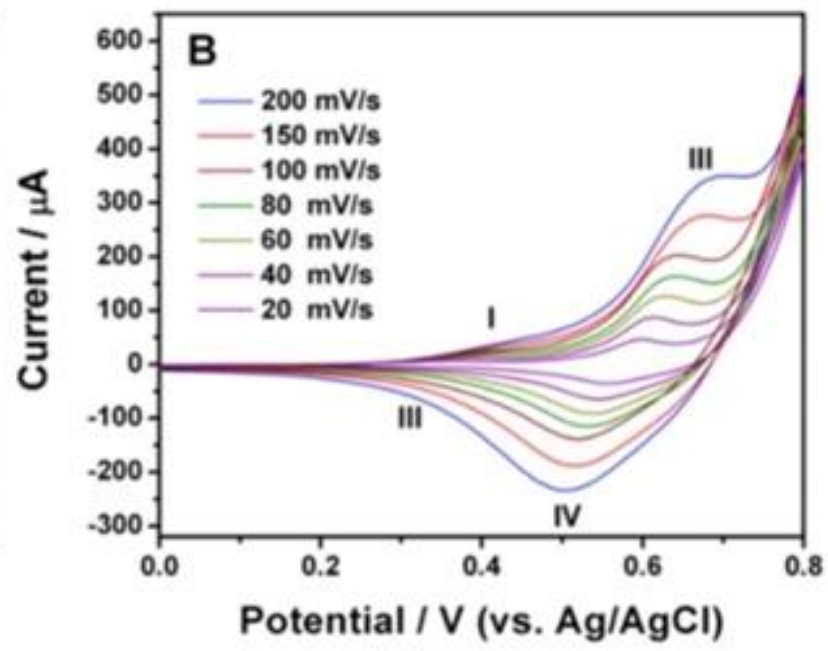

Fig. 3. (a) $\mathrm{CVs}$ of the Nafion/ $\mathrm{NH}-\mathrm{Co}_{3} \mathrm{O}_{4} \mathrm{NF} / \mathrm{GCE}$ in $0.1 \mathrm{M} \mathrm{NaOH}$ solution and in $0.1 \mathrm{M}$ pH 7.4 phosphate buffer solution at the scan rate of $100 \mathrm{mV} / \mathrm{s} ;(b) \mathrm{CVs}$ of the $\mathrm{Nafion} / \mathrm{NH}-\mathrm{Co}_{3} \mathrm{O}_{4} \mathrm{NFs} / \mathrm{GCE}$ in $0.1 \mathrm{M} \mathrm{NaOH}$ solution at various scan rates of 20, $4060,80100,150$, and $200 \mathrm{mV} / \mathrm{s}$ [71].

The electrochemical performance data of the $\mathrm{Co}_{3} \mathrm{O}_{4}$ nanostructures.

\begin{tabular}{|c|c|c|c|c|}
\hline Methods & Typical samples & Size, nm & Electrochemical performance & Ref. \\
\hline Precipitation method & $\mathrm{Co}_{3} \mathrm{O}_{4}$ nanoparticle & $20-30$ & $423 \mathrm{~mA} \cdot \mathrm{h} / \mathrm{g}$ at $0.1 \mathrm{C}$ after 40 cycles & [73] \\
\hline Electrospinning method & Porous $\mathrm{Co}_{3} \mathrm{O}_{4}$ nanofibers & $100-150$ & $\begin{array}{l}1000 \mathrm{~mA} \cdot \mathrm{h} / \mathrm{g} \text { at a current density of } 100 \\
\mathrm{~mA} \cdot \mathrm{g}^{-1} \text { after } 60 \text { cycles }\end{array}$ & {$[74]$} \\
\hline Solvothermal method & $\mathrm{Co}_{3} \mathrm{O}_{4}$ nanospheres & 30 & $1262 \mathrm{~mA} \cdot \mathrm{h} / \mathrm{g}$ at $0.1 \mathrm{C}$ after 100 cycles & {$[75]$} \\
\hline $\begin{array}{l}\text { An impregnation-reduction me- } \\
\text { thod followed by air-oxidation }\end{array}$ & $\begin{array}{l}\text { hollow structured } \mathrm{Co}_{3} \mathrm{O}_{4} \\
\text { nanoparticles }\end{array}$ & $50-100$ & $880 \mathrm{~mA} \cdot \mathrm{h} / \mathrm{g}$ at $50 \mathrm{~mA} / \mathrm{g}$ after 50 cycles & {$[76]$} \\
\hline Hydrother & \begin{tabular}{|l|}
$\begin{array}{l}\text { Polyhedral } \mathrm{Co}_{3} \mathrm{O}_{4} \text { nano- } \\
\text { particle }\end{array}$ \\
\end{tabular} & $<5$ & $\begin{array}{l}1017 \mathrm{~mA} \cdot \mathrm{h} / \mathrm{g} \text { at } 100 \mathrm{~mA} / \mathrm{g} \text { after } 100 \\
\text { cycles }\end{array}$ & {$[77]$} \\
\hline \multirow[t]{3}{*}{ Hydrothermal template method } & \multirow{3}{*}{$\begin{array}{l}\text { Mesoporous perforated } \\
\mathrm{Co}_{3} \mathrm{O}_{4} \text { nanoparticles }\end{array}$} & $100 \pm 10$ & $865.2 \mathrm{~mA} \cdot \mathrm{h} / \mathrm{g}$ after 100 cycles & \multirow[t]{3}{*}{ [78] } \\
\hline & & $150 \pm 20$ & $933.8 \mathrm{~mA} \cdot \mathrm{h} / \mathrm{g}$ after 100 cycles & \\
\hline & & $400 \pm 50$ & $1115.1 \mathrm{~mA} \cdot \mathrm{h} / \mathrm{g}$ after 100 cycles & \\
\hline Solve & $\begin{array}{l}\mathrm{Co}_{3} \mathrm{O}_{4} \text { nanoparticles/ na- } \\
\text { nographitic flakes }\end{array}$ & 35 & $780 \mathrm{~mA} \cdot \mathrm{h} / \mathrm{g}$ at $1000 \mathrm{~mA} / \mathrm{g}$ after 50 & {$[79]$} \\
\hline g and hydrother- & Porous $\mathrm{Co}_{3} \mathrm{O}_{4}$ nanofibers & $<100$ & $\begin{array}{l}900 \mathrm{~mA} \cdot \mathrm{h} / \mathrm{g} \text { after } 50 \text { cycles at } 1000 \mathrm{~mA} / \mathrm{g} \\
600 \mathrm{mAh} / \mathrm{g} \text { after } 50 \text { cycles at } 5000 \mathrm{~mA} / \mathrm{g}\end{array}$ & {$[80]$} \\
\hline Hydrother & $\begin{array}{|lll|}\begin{array}{l}\text { mesoporous } \\
\text { norods }\end{array} & \mathrm{Co}_{3} \mathrm{O}_{4} & \text { na- } \\
\end{array}$ & $100 \sim 150$ & $\begin{array}{l}1343.8 \mathrm{~mA} \cdot \mathrm{h} / \mathrm{g} \text { at } 500 \mathrm{~mA} \mathrm{~g}^{-1} \text { after } 200 \\
\text { cycles }\end{array}$ & {$[81]$} \\
\hline $\begin{array}{l}\text { Surfactant-assisted self-assembly } \\
\text { method }\end{array}$ & (2D) $\mathrm{Co}_{3} \mathrm{O}_{4}$ nanosheets & 1.90 & $\begin{array}{l}1868.6 \mathrm{~mA} \cdot \mathrm{h} / \mathrm{g} \text { at } 100 \mathrm{~mA} \mathrm{~g}^{-1} \text { after } 30 \\
\text { cycles }\end{array}$ & {$[82]$} \\
\hline $\begin{array}{l}\text { Wet chemical method and ly- } \\
\text { ophilization }\end{array}$ & $\begin{array}{l}\text { Carbon nano horn- } \mathrm{Co}_{3} \mathrm{O}_{4} \\
\text { nanoparticles }\end{array}$ & $10-15$ & $820 \mathrm{~mA} \cdot \mathrm{h} / \mathrm{g}$ at $1 \mathrm{Ag}^{-1}$ after 500 cycles & {$[83]$} \\
\hline Template-ass & $\mathrm{Co}_{3} \mathrm{O}_{4}$ nan & $15-30$ & $\begin{array}{l}921.2 \mathrm{~mA} \cdot \mathrm{h} / \mathrm{g} \text { at } 0.05 \mathrm{~A} \mathrm{~g}^{-1} \text { after } 60 \\
\text { cycles }\end{array}$ & {$[84]$} \\
\hline Hydrothermal method & $\mathrm{Co}_{3} \mathrm{O}_{4}$ nanocubes & $\sim 210-230$ & $873.5 \mathrm{~mA} \cdot \mathrm{h} / \mathrm{g}$ at $0.1 \mathrm{Ag}^{-1}$ after 50 cycles & {$[85]$} \\
\hline Cotton template route & $\begin{array}{l}\text { Carbon coated porous } \\
\mathrm{Co}_{3} \mathrm{O}_{4} \text { nanosheets }\end{array}$ & - & $\begin{array}{l}1735.4 \mathrm{~mA} \cdot \mathrm{h} / \mathrm{g} \text { at a current density of } \\
200 \mathrm{~mA} / \mathrm{g}\end{array}$ & |[86] \\
\hline
\end{tabular}


It was observed that $\mathrm{Co}_{3} \mathrm{O}_{4}$ containing a $2 \%$ mass fraction of $\mathrm{g}-\mathrm{C}_{3} \mathrm{~N}_{4}$ nanocomposite modified glassy carbon electrode shows excellent electrochemical performance towards the oxidation of hydrazine. Fu and co-workers [87] reported the synthesis of $\mathrm{Co}_{3} \mathrm{O}_{4}$ nanostructures with different morphology by adjusting the urea concentration using the microwave-hydrothermal method. They investigated the influence of morphology on the catalytic activity for oxygen evolution reaction (OER). Among three different morphologies, $\mathrm{Co}_{3} \mathrm{O}_{4}$ nanosheets exhibited superior electrochemical performance due to their high surface areas and porous structure. Wang et al. [88] enhanced the electrocatalytic activity of $2 \mathrm{D}$-micro-assembly $\mathrm{Co}_{3} \mathrm{O}_{4}$ nanosheets for $\mathrm{Li}_{-} \mathrm{O}_{2}$ batteries by tuning the concentration of oxygen vacancies and $\mathrm{Co}^{3+}$ ions and the discharge capacity was over $2000 \mathrm{~mA} \mathrm{~h} \mathrm{~g}^{-1}$ for 25 cycles at a current density of $100 \mathrm{~mA} \mathrm{~g}^{-1}$ for $\mathrm{Co}_{3} \mathrm{O}_{4}$ synthesized at $300^{\circ} \mathrm{C}$ hydrothermal temperature. Dhas and co-workers [89] evaluated degradation efficiencies of Rhodamine B, Methylene blue, and Methyl orange under visible light irradiation as 81,80 , and $57 \%$, respectively, in the presence of $\mathrm{Co}_{3} \mathrm{O}_{4}$ film catalyst. Philippot and collaborators [90] prepared $\mathrm{Co}_{3} \mathrm{O}_{4}$ nanoparticles by oxidation of Co nanoparticles in the air for 6 days at room temperature and used for water oxidation. $\mathrm{Co}_{3} \mathrm{O}_{4} \mathrm{NPs}$ covalent grafted with photosensitive polypyridyl-based $\mathrm{Ru}^{\mathrm{II}}$ complexes exhibited higher catalytic performance than simple mixtures of non-grafted photosensitizers and $\mathrm{Co}_{3} \mathrm{O}_{4} \mathrm{NPs}$.

Magnetic properties strongly depend on nanoparticle size, structure, and morphology. The magnetization of $\mathrm{Co}_{3} \mathrm{O}_{4} \mathrm{NPs}$ synthesized by the hydrothermal method increased from 0.09 to $0.34 \mathrm{emu} / \mathrm{g}$ with the increasing amount of $\mathrm{H}_{2} \mathrm{O}_{2}$ from 5 to $45 \mathrm{ml}$ due to the existence of oxygen in the spinel structure of oxide [30]. A.K.M. Atique Ullah et al. [91] implemented comparative magnetic measurements of $\mathrm{Co}_{3} \mathrm{O}_{4}$ NPs synthesized by co-precipitation method using different concentrations of $\mathrm{NaOH}$ (a strong base) and $\mathrm{NH}_{4} \mathrm{OH}$ (a weak base). They reported that the value of saturation magnetization was higher for high concentration $\mathrm{NaOH}$ synthesized $\mathrm{Co}_{3} \mathrm{O}_{4}$ nanoparticles than lower one, while opposite behavior was observed for $\mathrm{NH}_{4} \mathrm{OH}$ precipitant. N.K.Yetim [92] reported that the magnetic properties of $\mathrm{Co}_{3} \mathrm{O}_{4}$ nanostructures manufactured by the hydrothermal method using different precipitating agents. The results revealed that the hysteresis curve was observed only for nanosheets-like $\mathrm{Co}_{3} \mathrm{O}_{4}$ structures synthesized using urea. This nanostructure exhibited low ferromagnetic property, while poppy flower-like, clover field-like, and nanospheres-like $\mathrm{Co}_{3} \mathrm{O}_{4}$ structures synthesized using polyvinylpyrrolidone (PVP), ethylenediamine $\left(\mathrm{C}_{2} \mathrm{H}_{4}\left(\mathrm{NH}_{2}\right)_{2}\right)$, and $\mathrm{NaOH}$, respectively, showed antiferromagnetic behavior. It was explained by the fact that small-sized nanoparticles have small magnetic domains and this case results in low magnetic resistance. In another study [93], $\mathrm{Co} / \mathrm{Co}_{3} \mathrm{O}_{4}$ nanowires were prepared by thermal annealing in the temperature range $200-600^{\circ} \mathrm{C}$ of electrochemical deposited Co. The results showed that the nanostructures are completely oxidized with increasing temperature, a transition from the ferromagnetic to the paramagnetic behavior, a sharp increase in coercivity (two times), and a decrease in squareness values $\mathrm{Mr} / \mathrm{Ms}$ (more than 5 times) are observed. C. Ramamoorthy et al. [94] successfully synthesized $\mathrm{Co}_{3} \mathrm{O}_{4}$ with a particle size of $\sim 25-$ $30 \mathrm{~nm}$ through a wet chemical route using hexadecyl-trimethyl-ammonium-bromide as a cationic surfactant. The magnetic properties characterization at room temperature revealed that this sample has ferromagnetic behavior, saturation magnetization $\left(\mathrm{M}_{\mathrm{s}}\right)$ and coercivity is found to be $0.09 \mathrm{emu} / \mathrm{g}$ and $197 \mathrm{Oe}$, respectively. These results offered suitable features for applications in magnetic storage devices. G. Anandhababu and G. Ravi [95] investigated the influence of various surfactants, microwave reaction powers, and dopants on magnetic properties of $\mathrm{Co}_{3} \mathrm{O}_{4}$ nanostructures with hexagonal morphology synthesized by a simple microwave route. Using different surfactants such as $\mathrm{CTAB}$, citric acid, and hexamine affects the nanoparticle size. The smaller size is observed when utilizing CTAB and exhibits a higher magnetization $(0.0260$ emu/g ${ }^{-1}$ ) than hexamine added $\mathrm{Co}_{3} \mathrm{O}_{4}$. The ad- 
dition of hexamine leads to a bigger size of particles with higher agglomeration forming a bridge between two cobalt ions and lower magnetization values were observed. The magnetization value increased from $0.010 \mathrm{emu} / \mathrm{g}^{-1}$ to $0.0225 \mathrm{emu}^{-1}$ with increasing from $300 \mathrm{~W}$ to $650 \mathrm{~W}$ microwave power due to better structure and aligned morphology but decreased to $0.0160 \mathrm{emu} \mathrm{g}^{-1}$ with a further increment of microwave power up to $900 \mathrm{~W}$. In their work, Ni (similar ionic radius) and $\mathrm{Ce}$ (large ionic radius) were selected as dopants for $\mathrm{Co}_{3} \mathrm{O}_{4}$. They reported that $\mathrm{Ni}$-doped $\mathrm{Co}_{3} \mathrm{O}_{4}$ nanostructures showed ferromagnetic behavior due to the double exchange interaction between dopant ion and the structural defects, while $\mathrm{Ce}$ doped nanostructures had paramagnetic nature. Yin et al. [96] compared the magnetic properties of graphene- $\mathrm{Co}_{3} \mathrm{O}_{4} \quad\left(\mathrm{G}-\mathrm{Co}_{3} \mathrm{O}_{4}\right)$ nanocomposites synthesized by hydrothermal technique with the pure $\mathrm{Co}_{3} \mathrm{O}_{4}$ nanoparticles. They found that a small magnetic hysteresis loop was observed for pure $\mathrm{Co}_{3} \mathrm{O}_{4}$ nanoparticles at $5 \mathrm{~K}$ with a coercivity of $300 \mathrm{Oe}$ and a remanence of 0.01 $\mathrm{emu} / \mathrm{g}$, whereas, no loop appeared in $\mathrm{G}-\mathrm{Co}_{3} \mathrm{O}_{4}$ nanocomposites. Meanwhile, graphene- $\mathrm{Co}_{3} \mathrm{O}_{4}$ nanocomposites have higher magnetization and the magnetizations increase which decreasing temperature for two samples (Figure 4).

It is reported that the $M_{s}$ values varied from 0.11 to $0.06 \mathrm{Am}^{2} / \mathrm{kg}$ with different concentrations of $\mathrm{Zr}$ [59]. The weak ferromagnetic behavior was observed for $\mathrm{Zn}$-substituted $\mathrm{Co}_{3} \mathrm{O}_{4}$ nanoparticles due to uncompensated surface spins or finite size effect and the $\mathrm{M}_{\mathrm{s}}$ values increased compared to unsubstituted samples [60].

Summary and perspective. There are several approaches for synthesizing cobalt oxide nanoparticles, which have been refined in recently published researches. The most widely employed techniques for the synthesis of cobalt oxide nanostructures are summarized. Among them the precipitation method is very often used to obtain $\mathrm{Co}_{3} \mathrm{O}_{4}$ nanostructures because it is a facile and cheap approach. Recent advances have proved that cobalt oxide nanostructures are great potential materials for energy conversion and storage utilization because of their unusual physical and chemical properties. Controlling cobalt oxide nanostructures with an appropriate crystal size is important. The main reaction parameters influencing the size, structure, and morphology of nanoparticles there are also described. Morphology is one of the crucial factors along with size control which affects the properties of nanostructures. For instance, surface area, the number of reaction sites, the diffusion length of ions and electrons and the volume expansion from the insertion/extraction of Li ions also depend on the morphology at the material using in a Li-ion battery. Therefore development the new synthesis methods to obtain nanoparticles with desirable properties is required because the choice of an appropriate synthesis method also affects the properties of the obtained material.

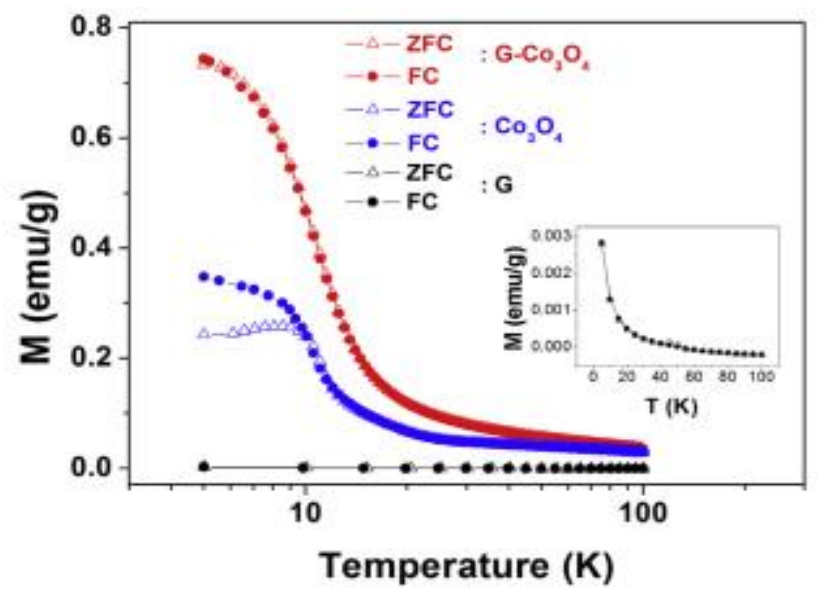

Fig. 4. Temperature dependence of the $\mathrm{ZFC}$ and $\mathrm{FC}$ magnetization curves in an applied field of $500 \mathrm{Oe}$ for $\mathrm{G}-\mathrm{Co}_{3} \mathrm{O}_{4}, \mathrm{Co}_{3} \mathrm{O}_{4}$, and Graphene, respectively [96]. 


\section{References}

1. Raghavender T., Ramesh K.G., Pravansu S.M. Nanostructured $\mathrm{Co}_{3} \mathrm{O}_{4}$ electrodes for supercapacitor applications from plasma spray technique. J. Power Sources. 2012. V. 209. P. 44-51.

2. Xu M., Wang F., Zhao M., Yang S., Song X. Molten hydroxides synthesis of hierarchical cobalt oxide nanostructure and its application as anode material for lithium ion batteries. Electrochimica Acta. 2011. V. 56. P. 4876-4881.

3. Vetter S., Haffer S., Wagner T., Tiemann M.. Nanostructured $\mathrm{Co}_{3} \mathrm{O}_{4}$ as a $\mathrm{CO}$ gas sensor: Temperature-dependent behavior. Sensors and Actuators B: Chemical. 2015. V. 206. P. 133-138.

4. Ronan B., Gregory C., Sabine V. Sonochemical oxidation of vanillyl alcohol to vanillin in the presence of a cobalt oxide catalyst under mild conditions. Ultrasonics Sonochemistry. 2017. V. 36. P. 27-35.

5. Haldorai Y., Kim J.Y., Ezhil A.T., Vilian, Heo N.S., Huh Y.S., Han Y. An enzyme-free electrochemical sensor based on reduced graphene oxide $\mathrm{Co}_{3} \mathrm{O}_{4}$ nanospindle composite for sensitive detection of nitrite. Sensors and Actuators B: Chemical. 2016. V. 227. P. 92-99.

6. Moon J., Kim T.K., VanSaders B., Choi C., Liu Z., Jin S., Chen R. Black oxide nanoparticles as durable solar absorbing material for hightemperature concentrating solar power system. Solar Energy Material s\& Solar Cells. 2015. V. 134. P. 417-424.

7. Wang L., Song X., Zheng Y. Electrochromic properties of nanoporous $\mathrm{Co}_{3} \mathrm{O}_{4}$ thin films prepared by electrodeposition method. Micro \& Nano Letters. 2012. V. 7. P. 1026-1029.

8. Nethravathi C., Sen S., Ravishankar N., Rajamathi M., Pietzonka C., Harbrecht B. Ferrimagnetic Nanogranular $\mathrm{Co}_{3} \mathrm{O}_{4}$ through Solvothermal Decomposition of Colloidally Dispersed Monolayers of $\alpha$-Cobalt Hydroxide. J. Phys. Chem. B. 2005. V. 109. P. $11468-11472$.

9. Dong Q., Wang X., Willis W.S., Song D., Huang Y., Zhao J., Li B., Lei Y. Nitrogen-doped Hollow $\mathrm{Co}_{3} \mathrm{O}_{4}$ Nanofibers for both Solid-state $\mathrm{pH}$ Sensing and Improved Non-enzymatic Glucose Sensing. Electroanalysis. 2019. V. 31. P. 1- 11.

10. Mishra S., Yogi P., Sagdeo P.R., Kumar R. $\mathrm{TiO}_{2}-$ $\mathrm{Co}_{3} \mathrm{O}_{4}$ core-shell nanorods: bifunctional role in better energy storage and electrochromism. ACS Appl. Energy Mater. 2018. V. 1. P. 790-798.

11. Kupfer B., Majhi K., Keller D.A. Thin film $\mathrm{Co}_{3} \mathrm{O}_{4} / \mathrm{TiO}_{2}$ heterojunction solar cells. Adv. Energy Mater. 2015. V. 5. P. 1401007.

12. Shi X., Han S., Sanedrin R.J., Zhou F. and Selke M. Synthesis of Cobalt Oxide Nanotubes from Colloidal Particles Modified with a Co(III)Cysteinato Precursor. Chem. Mater. 2002. V. 14. P. 1897-1902.
13. Ding Y., Wang Y., Su L., Bellagamba M., Zhang $\mathrm{H}$., Electrospun Y.Lei. $\mathrm{Co}_{3} \mathrm{O}_{4}$ nanofibers for sensitive and selective glucose detection. Biosensors and Bioelectronics. 2010. V. 26. P. 542-548.

14. Vickers D., Archer L.A., Floyd-Smith T. Synthesis and characterization of cubic cobalt oxide nanocomposite fluids. Colloids and Surfaces A: Physicochem. Eng. Aspects. 2009. V. 348. P. 39-44.

15. Ozkaya T., Baykal A., Toprak M.S., Koseoğlu Y., Durmuş Z. Reflux synthesis of $\mathrm{Co}_{3} \mathrm{O}_{4}$ nanoparticles and its magnetic characterization. Journal of Magnetism and Magnetic Materials. 2009. V. 321. P. 2145-2149.

16. Bhatte K.D., Bhanage B.M. Synthesis of cobalt oxide nanowires using a glycerol thermal route. Materials Letters. 2013. V. 96. P. 60-62.

17. Zhang Y., Chen Y., Wang T., Zhou J., Zhao Y. Synthesis and magnetic properties of nanoporous $\mathrm{Co}_{3} \mathrm{O}_{4}$ nanoflowers. Microporous and Mesoporous Materials. 2008. V. 114. P. 257-261.

18. Wu J., Dai Y., Pan Z., Huo D., Wang, T. Zhang $\mathrm{H}$., $\mathrm{Hu}$ J., Yan $\mathrm{S} . \mathrm{Co}_{3} \mathrm{O}_{4}$ hollow microspheres on polypyrrole nanotubes network enabling long-term cyclability sulfur cathode. Applied Surface Science. 2020. V. 510. P. 145529.

19. Wadekar K.F., Nemade K.R. and Waghuley S.A. Chemical synthesis of cobalt oxide $\left(\mathrm{Co}_{3} \mathrm{O}_{4}\right)$ nanoparticles by co-precipitation method. Research J. Chemical Sciencies. 2017. V. 7. P. 53-55.

20. Viljoen E.L., Moloto M.J., Thabede P.M. Impact of acetate ions on the shape of $\mathrm{Co}_{3} \mathrm{O}_{4}$ nanoparticles. Digest Journal of Nanomaterials and Biostructures. 2017. V. 12. P. 571-577.

21. Allaedini G. and Muhammad A. Study of influential factors in synthesis and characterization of cobalt oxide nanoparticles. J. Nanostructure in Chemistry. 2013. V. 3. P. 1-16.

22. Sharifi S.L., Shakur H.R., Mirzaei A. Characterization of Cobalt Oxide $\mathrm{Co}_{3} \mathrm{O}_{4}$ Nanoparticles Prepared by Various Methods: Effect of Calcination Temperatures on Size, Dimension and Catalytic Decomposition of Hydrogen Peroxide. Int. J. Nanosci. Nanotechnol. 2013. V. 9. P. 51-58.

23. Xu J.M., Zhang J., Wang B.B., Liu F. Shaperegulated synthesis of cobalt oxide and its gassensing property. Journ. of Alloys and Compounds. 2015. V. 619. P. 361-367.

24. Luisetto I., Pepe F., Bemporad E. Preparation and characterization of nano cobalt oxide. J Nanopart Res. 2008. V. 10. P. 59-67.

25. Abdelhak L., Bedhiaf B., Amar B., Cherifa D., Benhebal $\mathrm{H}$. Tuning of the physical properties by various transition metal doping in $\mathrm{Co}_{3} \mathrm{O}_{4}: \mathrm{TM}$ $(\mathrm{TM}=\mathrm{Ni}, \mathrm{Mn}, \mathrm{Cu}$ ) thin films: A comparative study. Chinese J. Physics. 2018. V. 56. P. 1845-1852.

26. Katalin Sinko, Geza Szabo, and Miklos Zrinyi. Liquid-Phase Synthesis of Cobalt Oxide Nanoparticles. Journal of Nanoscience and Nanotechnology. 2011. V. 11. P. 1-9. 
27. Shadrokh S., Farahmandjou M. and Firozabadi T.P. Fabrication and Characterization of Nanoporous Co Oxide $\left(\mathrm{Co}_{3} \mathrm{O}_{4}\right)$ Prepared by Simple Solgel Synthesis. Phys. Chem. Res. 2016. V. 4. P. 153-160.

28. Devi V.S., Athika M., Duraisamy E., Prasath A., Sharma A.S., Elumalai P. Facile sol-gel derived nanostructured spinel $\mathrm{Co}_{3} \mathrm{O}_{4}$ as electrode material for high-performance supercapattery and lithiumion storage. J. Energy Storage. 2019. V. 25. P. 100815.

29. Wang G., Shen X., Horvat J., Wang B., Liu H., Wexler D., Yao J. Hydrothermal Synthesis and Optical, Magnetic, and Supercapacitance Properties of Nanoporous Cobalt Oxide Nanorods. J. Phys. Chem. C. 2009. V. 113. P. 4357-4361.

30. Hashemi Amiri S.E., Vaezi M.R. and Kandjani A.E. A comparison between hydrothermally prepared $\mathrm{Co}_{3} \mathrm{O}_{4}$ via $\mathrm{H}_{2} \mathrm{O}_{2}$ assisted and calcination methods. J. Ceramic Processing Res. 2011. V. 12. P. 327-331.

31. Nassar M.Y. Size-controlled synthesis of $\mathrm{CoCO}_{3}$ and $\mathrm{Co}_{3} \mathrm{O}_{4}$ nanoparticles by free-surfactant hydrothermal method. Materials Letters. 2013. V. 94. P. 112-115.

32. Nugroho A., Kim J. Effect of $\mathrm{KOH}$ on the continuous synthesis of cobalt oxide and manganese oxide nanoparticles in supercritical water. J. Ind. Eng. Chem. 2014. V. 20. P. 4443-4446.

33. Elhag S., Ibupoto Z.H., Nour O., Willander M. Synthesis of $\mathrm{Co}_{3} \mathrm{O}_{4}$ Cotton-Like Nanostructures for Cholesterol Biosensor. Materials. 2015. V. 8. P. 149-161.

34. Sun S., Zhao X., Yang M., Ma L. and Shen X. Facile and Eco-Friendly Synthesis of Finger-Like $\mathrm{Co}_{3} \mathrm{O}_{4}$ Nanorods for Electrochemical Energy Storage. Nanomaterials. 2015. V. 5. P. 2335-2347.

35. Ma J., Zhang S., Liu W., Zhao Y. Facile preparation of $\mathrm{Co}_{3} \mathrm{O}_{4}$ nanocrystals via a solvothermal process directly from common $\mathrm{Co}_{2} \mathrm{O}_{3}$ powder. J. Alloys and Compounds. 2010. V. 490. P. 647-651.

36. Nassar M.Y., Mohamed T.Y., Ahmed I.S. One-pot solvothermal synthesis of novel cobalt salicylaldimine-urea complexes: A new approach to $\mathrm{Co}_{3} \mathrm{O}_{4}$ nanoparticles. J. Molecular Structure. 2013. V. 1050. P. 81-87.

37. Pang M., Long G., Jiang S., Ji Y., Han W., Wang B., Liu X., Xi Y., Wang D., Xu F. Ethanolassisted solvothermal synthesis of porous nanostructured cobalt oxides $\left(\mathrm{CoO} / \mathrm{Co}_{3} \mathrm{O}_{4}\right)$ for high-performance supercapacitors. Chem. Eng. J. 2015. V. 280. P. 377-384.

38. Al-Qirby L.M., Radiman S., Siong C.W., Ali A.M. Sonochemical synthesis and characterization of $\mathrm{Co}_{3} \mathrm{O}_{4}$ nanocrystals in the presence of the ionic liquid [EMIM][BF4], Ultrasonics Sonochem. 2017. V. 38. P. 640-651.
39. Askarinejad A.and Morsali A. Direct ultrasonicassisted synthesis of sphere-like nanocrystals of spinel $\mathrm{Co}_{3} \mathrm{O}_{4}$ and $\mathrm{Mn}_{3} \mathrm{O}_{4}$. Ultrasonics Sonochem. 2009. V. 16. P. 124-131.

40. Kamar E.M. and Reda S.M. Sonochemical method for synthesizing $\mathrm{Co}_{3} \mathrm{O}_{4}$ /graphene nanocomposites for use as counter electrode in dye-sensitized solar Cells. Appl. Phys. A. 2016. V. 122. P. 688.

41. Xia X.H., Tu J.P., Zhang J., Huang X.H., Wang X.L., Zhang W.K., Huang H. Enhanced electrochromics of nanoporous cobalt oxide thin film prepared by a facile chemical bath deposition. Electrochemistry Communications. 2008. V. 10. P. 1815-1818.

42. Li Y., Huang K., Yao Z., Liu S., Qing X. $\mathrm{Co}_{3} \mathrm{O}_{4}$ thin film prepared by a chemical bath deposition for electrochemical capacitors. Electrochimica Acta. 2011. V. 56. P. 2140-2144.

43. Kandalkar S.G., Gunjakar J.L., Lokhande C.D., Joo O. Synthesis of cobalt oxide interconnected flacks and nano-worms structures using low temperature chemical bath deposition. J. Alloys and Compounds. 2009. V. 478. P. 594-598.

44. Kandalkar S.G., Dhawale D.S., Chang-Koo Kim. Chemical synthesis of cobalt oxide thin film electrode for supercapacitor application. Synthetic Metals. 2010. V. 160. P. 1299-1302.

45. Kung C., Lina C., Vittal R., Ho K. Synthesis of cobalt oxide thin films in the presence of various anions and their application for the detection of acetaminophen. Sensors and Actuators. B. 2013. V. 182. P. 429-438.

46. Obodo R.M., Nwanya A.C., Ekwealor A.B.C., Ahmad I., Zhao T., Osuji R.U., Maaza M., Ezema F.I. Influence of $\mathrm{pH}$ and annealing on the optical and electrochemical properties of cobalt (III) oxide $\left(\mathrm{Co}_{3} \mathrm{O}_{4}\right)$ thin films. Surfaces and Interfaces. 2019. V. 16. P. 114-119.

47. Martínez-Gil M., Cabrera-German D., PintorMonroy M.I., García-Valenzuela J.A., Cota-Leal M., De W. la Cruz, Quevedo-Lopez M.A., PérezSalas R., Sotelo-Lerma M. Effect of annealing temperature on the thermal transformation to cobalt oxide of thin films obtained via chemical solution deposition. Materials Science in Semiconductor Processing. 2020. V. 107. P. 104825.

48. Valanarasu S., Dhanasekaran V., Karunakaran M., Chandramohan R., Mahalingam T. Role of Solution $\mathrm{pH}$ on the Microstructural Properties of Spin Coated Cobalt Oxide Thin Films. J. of Nanosci. Nanotechnol. 2013. V. 13. P. 1-6.

49. Abdelhak L., Bedhiaf B., Amar B., Cherifa D., Benhebal $\mathrm{H}$. Tuning of the physical properties by various transition metal doping in $\mathrm{Co}_{3} \mathrm{O}_{4}$ : TM ( $\mathrm{TM}=\mathrm{Ni}, \mathrm{Mn}, \mathrm{Cu}$ ) thin films: A comparative study. Chin. J. Physics. 2018. V. 56. P. 18451852. 
50. Patil V., Joshi P., Chougule M., S. Sen. Synthesis and Characterization of $\mathrm{Co}_{3} \mathrm{O}_{4}$ Thin Film. Soft Nanosci. Letters. 2012. V. 2. P. 1-7.

51. Khansari A., Salavati-Niasari M., Gholamrezaei S. Solid State Synthesis of Cobalt Oxide Nanohexagonales. Synthesis and Reactivity in Inorganic, Metal-Organic, and Nano-Metal Chemistry. 2015. V. 45. P. 1063-1068.

52. Khalaji A.D. Synthesis, Characterization and Optical Properties of $\mathrm{Co}_{3} \mathrm{O}_{4}$ Nanoparticles. Asian J. Nanosci. Materials. 2019. V. 2. P. 186-190.

53. Farhadi S., Safabakhsh J. and Zaringhadam P. Synthesis, characterization, and investigation of optical and magnetic properties of cobalt oxide $\left(\mathrm{Co}_{3} \mathrm{O}_{4}\right)$ nanoparticles. J. Nanostruct in Chem. 2013. V. 3. P. 1-9.

54. Zhang Y., Chen Y., Wang T., Zhou J., Zhao Y. Synthesis and magnetic properties of nanoporous $\mathrm{Co}_{3} \mathrm{O}_{4}$ nanoflowers. Micropor. Mesopor. Mater. 2008. V. 114. P. 257-261.

55. Feng C., Wang H., Zhang J., Hu W., Zou Z. \& Deng Y. One-pot facile synthesis of cobalt oxide nanocubes and their magnetic properties. J. Nanopart Res. 2014. V. 16. P. 2413.

56. Turan E., Zeybekoğlu E., Kul M. Effects of bath temperature and deposition time on $\mathrm{Co}_{3} \mathrm{O}_{4}$ thin films produced by chemical bath deposition. Thin Solid Films. 2019. V. 692. P. 137632.

57. Elaakib H., Pierson J.F., Chaik M., Samba C., Ait Dads H., Narjis A., Outzourhit A. Evolution of the structural, morphological, optical and electrical properties of reactively RF-sputtered cobalt oxide thin films with oxygen pressure. Vacuum. 2019. V. 159. P. 346-352.

58. Ambika S., Gopinath S., Saravanan K., Sivakumar K., Ragupathi C., Sukantha T.A. Structural, morphological and optical properties and solar cell applications of thioglycolic routed nano cobalt oxide material. 2019. V. 5. P. 305-309.

59. Alla S.K., Duvuru H.B., Shaw S.K., Vara Prasad B.B.V.S., Kumar M.K., Meena S.S., Gupta N., Prasad N.K. Zr-substituted cobalt oxide nanoparticles: structural, magnetic and electrical properties. Journal of Materials Science: Materials in Electronics. 2019. V. 30. P. 20088-20098.

60. Duvuru H.B., Alla S.K., Shaw S.K., Meena S.S., Gupta N., Vara Prasad B.B.V.S., Kothawale M.M., Kumar M.K., Prasad N.K. Magnetic and dielectric properties of $\mathrm{Zn}$ substituted cobalt oxide nanoparticles. Ceramics Int. 2019. V. 45. P. 16512-16520.

61. Kalam K., Seemen H., Mikkor M., Jõgiaas T., Ritslaid P., Tamm A., Kukli K., Kasikov A., Link J., Stern R., Dueñas S., Castán H. Electrical and magnetic properties of atomic layer deposited cobalt oxide and zirconium oxide nanolaminates. 2019. V. 669. P. 294-300.
62. El A.M. Sayed and El-Gamal S. Synthesis and investigation of the electrical and dielectric properties of $\mathrm{Co}_{3} \mathrm{O}_{4} /(\mathrm{CMC}+\mathrm{PVA})$ nanocomposite films. J. Polym Res. 2015. V. 22. P. 97.

63. Durano M.M., Tamboli A.H., Kim H. Cobalt oxide synthesized using urea precipitation method as catalyst for the hydrolysis of sodium borohydride. Colloids and Surfaces A: Physicochem. Eng. Aspects. 2017. V. 520. P. 355-360.

64. Ashraf Janjua M.R.S. Synthesis of $\mathrm{Co}_{3} \mathrm{O}_{4}$ Nano Aggregates by Co-precipitation Method and its Catalytic and Fuel Additive Applications. Open Chem. 2019. V. 17. P. 865-873.

65. Pudukudy M., Yaakob Z.. Sol-gel synthesis, characterisation, and photocatalytic activity of porous spinel $\mathrm{Co}_{3} \mathrm{O}_{4}$ nanosheets Chemical Papers. 2014. V. 68. P. 1087-1096.

66. Farhadi S., Javanmard M. and Nadri G. Characterization of Cobalt Oxide Nanoparticles Prepared by the Thermal Decomposition of $\left[\mathrm{Co}\left(\mathrm{NH}_{3}\right)_{5}\left(\mathrm{H}_{2} \mathrm{O}\right)\right]\left(\mathrm{NO}_{3}\right)_{3}$ Complex and Study of Their Photocatalytic Activity. Acta Chim. Slov. 2016. V. 63. P. 335-343.

67. Kang M. and Zhou H. Facile Synthesis and Structural Characterization of $\mathrm{Co}_{3} \mathrm{O}_{4}$ Nanocubes. AIMS Mater. Science. 2015. V. 2. P. 16-27.

68. Ren Q., Feng Z., Mo S., Huang C., Li S., Zhang W., Chen L., Fu M., Wu J., Ye D. 1D- $\mathrm{Co}_{3} \mathrm{O}_{4}, 2 \mathrm{D}-$ $\mathrm{Co}_{3} \mathrm{O}_{4}, 3 \mathrm{D}-\mathrm{Co}_{3} \mathrm{O}_{4}$ for catalytic oxidation of toluene. Catalysis Today. 2019. V. 332. P. 160-167.

69. Kung C., Lin C., Li T., Vittal R., Ho K. Synthesis of $\mathrm{Co}_{3} \mathrm{O}_{4}$ thin films by chemical bath deposition in the presence of different anions and application to $\mathrm{H}_{2} \mathrm{O}_{2}$ sensing. Procedia Eng. 2011. V. 25. P. 847850 .

70. Behling R., Chatel G., Valange S. Sonochemical oxidation of vanillyl alcohol to vanillin in the presence of a cobalt oxide catalyst under mild conditions. Ultrasonics Sonochem. 2017. V. 36. P. 27-35.

71. Dong Q., Wang X., Willis W.S., Song D., Huang Y., Zhao J., Li B. and Lei Y. Nitrogen-doped Hollow $\mathrm{Co}_{3} \mathrm{O}_{4}$ Nanofibers for both Solid-state $\mathrm{pH}$ Sensing and Improved Non-enzymatic Glucose Sensing. Electroanal. 2019. V. 31. P. 1-11.

72. Dai G., Xie J., Li C., Liu S. Flower-like $\mathrm{Co}_{3} \mathrm{O}_{4}$ /graphitic carbon nitride nanocomposite based electrochemical sensor and its highly sensitive electrocatalysis of hydrazine. J. Alloys and Compounds. 2017. V. 727. P. 43-51.

73. Palani S.and Arumugam S. Nano $\mathrm{Co}_{3} \mathrm{O}_{4}$ as Anode Material for $\mathrm{Li}$-Ion and Na-Ion Batteries: An Insight into Surface Morphology. Chemistry Select. 2018. V. 3. P. 5040-5049.

74. Fan L., Zhang W., Zhu S., and Lu Y. Enhanced Lithium Storage Capability in Li-Ion Batteries Using Porous $3 \mathrm{D} \mathrm{Co}_{3} \mathrm{O}_{4}$ Nanofiber Anodes. Ind. Eng. Chem. Res. 2017. V. 56. P. 2046-2053. 
75. Wang Y., Guo R., Liu W., Zhu L., Huang W., Wang W., Zheng $\mathrm{H} . \mathrm{Co}_{3} \mathrm{O}_{4}$ nanospheres composed of highly interconnected nanoparticles for boosting Li-Ion storage. J. Power Sources. 2019. V. 444. P. 227260.

76. Wang D., Yu Y., He H., Wang J., Zhou W., Abruña H.D. Template-Free Synthesis of Hollow Structured $\mathrm{Co}_{3} \mathrm{O}_{4}$ Nanoparticles as High-Performance Anodes for Lithium-Ion Batteries. ACS Nano. 2015. V. 9. P. 1775-1781.

77. Zheng F., Wei L. Synthesis of ultrafine $\mathrm{Co}_{3} \mathrm{O}_{4}$ nanoparticles encapsulated in nitrogen-doped porous carbon matrix as anodes for stable and long-life lithium ion battery. J. Alloys and Compounds. 2019. V. 790. P. 955-962.

78. Park J.S., Shin D.O., Lee C.S., Lee Y., Kim J.Y., Kim K.M., Shin K. Mesoporous perforated $\mathrm{Co}_{3} \mathrm{O}_{4}$ nanoparticles with a thin carbon layer for high performance Li-ion battery anodes. Electrochimica Acta. 2018. V. 264. P. 376-385.

79. Keshmarzi M.K., Daryakenari A.A., Omidvar H., Javanbakht M., Ahmadi Z., Delaunay J., Badrnezhad R. Pulsed electrophoretic deposition of nanographitic flakenanostructured $\mathrm{Co}_{3} \mathrm{O}_{4}$ layers for efficient lithium-ion-battery anode. J. Alloys and Compounds. 2019. V. 805. P. 924-933.

80. Hu R., Zhang H., Bu Y., Zhang H., Zhao B., Yang C. Porous $\mathrm{Co}_{3} \mathrm{O}_{4}$ nanofibers surface-modified by reduced graphene oxide as a durable, high-rate anode for lithium ion battery. Electrochim. Acta. 2017. V. 228. P. 241-250.

81. Wang B., Wang S., Tang Y., Ji Y., Liu W., Lu X. Hydrothermal Synthesis of Mesoporous $\mathrm{Co}_{3} \mathrm{O}_{4}$ Nanorods as High Capacity Anode Materials for Lithium Ion Batteries. Energy Procedia. 2019. V. 158. P. 5293-5298.

82. Yang J., Gao M., Lei J., Jin X., Yu L., Ren F. Surfactant-assisted synthesis of ultrathin twodimensional $\mathrm{Co}_{3} \mathrm{O}_{4}$ nanosheets for applications in lithium-ion batteries and ultraviolet photodetector. J. Solid State Chem. 2019. V. 274. P. 124-133.

83. Dwivedi P.K., G. Parte, M. Thripuranthaka, M. V. Shelke. High efficiency lithium storage in 3D composite foam of $\mathrm{Co}_{3} \mathrm{O}_{4}$ nanoparticles integrated carbon nanohorns. Mater. Sci. Eng. 2021. V. 263. P. 114839.

84. Wang H., Zhu Y., Yuan C., Li Y., Duan Q. Cobalt-phthalocyanine-derived ultrafine $\mathrm{Co}_{3} \mathrm{O}_{4}$ nanoparticles as high-performance anode materials for lithium ion batteries. Appl. Surface Sci. 2017. V. 414. P. 398-404.

85. Liu Y., Wan H., Jiang N., Zhang W., Zhang H., Chang B., Wang Q., Zhang Y., Wang Z., Luo S., Sun H. Chemical reduction-induced oxygen defi- ciency in $\mathrm{Co}_{3} \mathrm{O}_{4}$ nanocubes as advanced anodes for lithium ion batteries. Solid State Ionics. 2019. V. 334. P. 117-124.

86. Deng J., Lv X., Zhong J., Sun X. Carbon coated porous $\mathrm{Co}_{3} \mathrm{O}_{4}$ nanosheets derived from cotton fibers as anodes for superior lithium ion batteries. Appl. Surface Sci. 2019. V. 475. P. 446-452.

87. Zhang L., Li H., Li K., Li L., Wei J., Feng L., Fu Q. Morphology-controlled fabrication of $\mathrm{Co}_{3} \mathrm{O}_{4}$ nanostructures and their comparative catalytic activity for oxygen evolution reaction. J. Alloys and Compounds. 2016. V. 680. P. 146-154.

88. Hou Y., Hou C., Zhai Y., Li H., Chen T., Fan Y., Wang H., Wang W. Enhancing the electrocatalytic activity of $2 \mathrm{D}$ micro-assembly $\mathrm{Co}_{3} \mathrm{O}_{4}$ nanosheets for $\mathrm{Li}-\mathrm{O}_{2}$ batteries by tuning oxygen vacancies and $\mathrm{Co}^{3+} / \mathrm{Co}^{2+}$ ratio. Electrochim. Acta. 2019. V. 324. P. 134884.

89. Dhas C.R., Venkatesh R., Kirubakaran D.D., Merlin J.P., Subramanian B., Ezhil Raj A.M. Electrochemical sensing of glucose and photocatalytic performance of porous $\mathrm{Co}_{3} \mathrm{O}_{4}$ films by nebulizer spray technique. 2017. V. 186. P. 561-573.

90. Philippot K., De Tovar J., Romero N., Denisov S.A. Light-driven water oxidation using hybrid photosensitizer-decorated $\mathrm{Co}_{3} \mathrm{O}_{4}$ nanoparticles. 2018. V. 9. P. 506-515.

91. Atique Ullah A.K.M., Amin F.B., Hossain A. Tailoring surface morphology and magnetic property by precipitants concentrations dependent synthesis of $\mathrm{Co}_{3} \mathrm{O}_{4}$ nanoparticles. Ceramics Int. 2020. V. 46. P. 27892-27896.

92. Yetim N.K. Hydrothermal synthesis of $\mathrm{Co}_{3} \mathrm{O}_{4}$ with different morphology: Investigation of magnetic and electrochemical properties. J. Molecular Structure. 2021. V. 1226. P. 129414.

93. Zdorovets M.V., Shumskaya A.E., Kozlovskiy A.L. Investigation of the effect of phase transformations on the magnetic and electrical properties of $\mathrm{Co} / \mathrm{Co}_{3} \mathrm{O}_{4}$ nanowires. J. Magnetism and Magnetic Mater. 2020. V. 497. P. 166079.

94. Ramamoorthy C., Rajendran V. Effect of surfactants assisted $\mathrm{Co}_{3} \mathrm{O}_{4}$ nanoparticles and its structural, optical, magnetic and electrochemical properties. Optik. 2017. V. 145. P. 330-335.

95. Anandhababu G., Ravi G. Facile synthesis of quantum sized $\mathrm{Co}_{3} \mathrm{O}_{4}$ nanostructures and their magnetic properties. Nano-Structures \& NanoObjects. 2018. V. 15. P. 1-9.

96. Yin K., Ji J., Shen Y., Xiong Y., Bi H., Sun J., Xu T., Zhu Z., Sun L. Magnetic properties of $\mathrm{Co}_{3} \mathrm{O}_{4}$ nanoparticles on graphene substrate. J. Alloys and Compounds. 2017. V. 720. P. 345-351. 


\section{KOBALT OKSID NANOQURULUŞLARININ SINTEZİ Və XARAKTERISTIKASI QISA İCMAL MӘQALə}

\section{S.C.Məmmədyarova}

Son zamanlarda əla xüsusiyyətlərə malik nanoölçülü keçid metal oksidləri bir sıra texnoloji sahələr üçün yeni bir material sinifinə çevrilmişdir. Son tərəqqi göstərir ki, keçid metalların oksidləri arasında kobalt oksid nanohissəcikləri qeyri-adi xüsusiyyətlərinə və optoelektron qurğuda, yüksək tutumlu kondensatorlarda, Li-ion batareyada, qaz sensorlarda və elektroxrom cihazlarında perspektivli tətbiqinə görə geniş diqqət toplamışdır. Bu icmal məqalə kobalt oksid nanohissəciklərinin sintezi ilə bağlı son yenilikləri əhatə edir. Bu günə qədər kobalt oksid nanohissəciklərinin müxtəlif sintez üsulları mövcuddur. Müxtəlif prekursorlardan alınan kobalt oksid nanohissəcikləri fərqli ölçü paylanması, eyni zamanda fərqli optik, elektrik, maqnit və elektrokimyəvi xüsusiyyətləri göstərir. Həqiqətən hissəciyin ölçüsünün nanometr ölçüyə qədər kiçilməsi kvant ölçü effekti səbəbindən həcmli nümunələrlə müqayisədə xassələrin dəyişməsinə gətirib çıxarır. Tətbiq sahəsindən asılı olaraq arzuolunan xüsusiyyətlərə malik nanohissəciklər üçün uyğun sintez metodunun seçimi vacib amildir. Bu icmal məqalənin məqsədi kobalt oksid nanohissəciklərinin sintez üsulları haqqunda geniş məlumat verməkdir.

Açar sözlor: kobalt oksid, kristal ölçüsü, yüksək tutumlu kondensator.

\section{СИНТЕЗ И ХАРАКТЕРИСТИКА НАНОСТРУКТУР ОКСИДА КОБАЛЬТА КРАТКИЙ ОБЗОР}

\section{С.Дж.Мамедъйарова}

В последнее время наноструктурированные оксиды переходных металлов с ценными свойствами стали новым классом материалов для ряда технологических областей. Наночастицы оксида кобальта привлекли большое внимание из-за их необычных свойств и перспективных применений в оптоэлектронных устройствах, суперконденсаторах, литий-ионных батареях, газовых сенсорах и электрохромных устройствах. Рассмотрены последние достижения в области синтеза наночастиц оксида кобальта. сегодняшний день доступны различные методы синтеза наночастиц оксида кобальта. Наночастицы оксида кобальта, полученные из различных предшественников, показывают различное распределение по размерам, а также различные оптические, электрические, магнитные и электрохимические свойства. Уменьшение размера частиц до нанометрового масштаба приводит к изменениям свойств по сравнению с объемными из-за квантовых размерных эффектов. В зависимости от области применения, выбор подходящего метода синтеза наночастиц с желаемыми свойствами является решающим фактором. Целью данной обзорной работы является предоставление дополнительной информации о методах синтеза наночастиц оксида кобальта.

Ключевые слова: оксид кобальта, размер кристаллитов, суперконденсатор. 